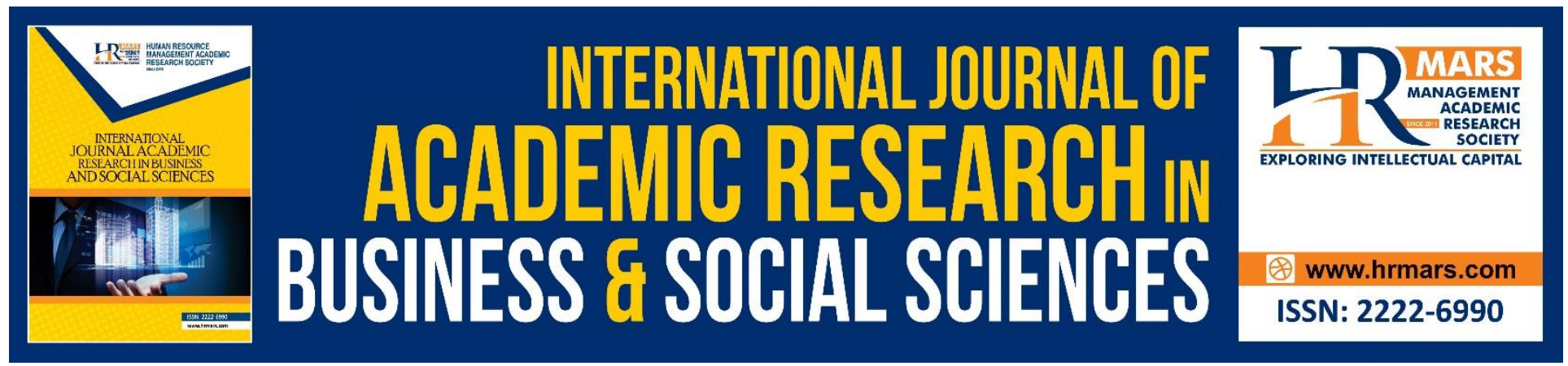

\title{
The Impact of Inbound Tourism on Economic Growth of Nepal
}

\author{
Rauniyar Ashish Kumar
}

To Link this Article: http://dx.doi.org/10.6007/IJARBSS/v9-i3/5647

DOI: $\quad 10.6007 /$ IJARBSS/v9-i3/5647

Received: 15 Feb 2019, Revised: 08 March 2019, Accepted: 21 March 2019

Published Online: 07 April 2019

In-Text Citation: (Kumar, 2019)

To Cite this Article: Kumar, R. A. (2019). The Impact of Inbound Tourism on Economic Growth of Nepal. International Journal of Academic Research in Business and Social Sciences, 9(3), 183-195.

\section{Copyright: (c) 2019 The Author(s)}

Published by Human Resource Management Academic Research Society (www.hrmars.com)

This article is published under the Creative Commons Attribution (CC BY 4.0) license. Anyone may reproduce, distribute, translate and create derivative works of this article (for both commercial and non-commercial purposes), subject to full attribution to the original publication and authors. The full terms of this license may be seen at: http://creativecommons.org/licences/by/4.0/legalcode

Vol. 9, No. 3, 2019, Pg. 183 - 195

Full Terms \& Conditions of access and use can be found at http://hrmars.com/index.php/pages/detail/publication-ethics 


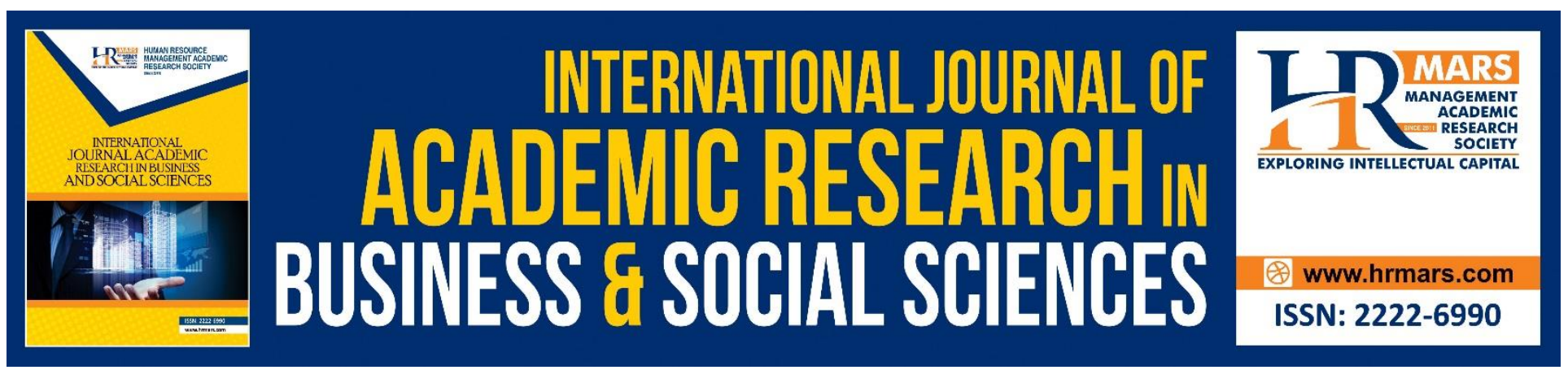

\title{
The Impact of Inbound Tourism on Economic Growth of Nepal
}

\author{
Rauniyar Ashish Kumar \\ College of Economics and Management, Nanjing University of Aeronautics and Astronautics, \\ Nanjing, China \\ Email: rauniyarashishkumar@outlook.com
}

\begin{abstract}
This study examines the relationship between tourism and economic growth in Nepal by considering the relative importance of financial development. The newly developed Bayer and Hank joint test results show that tourism, economic growth and financial development are co-integration. The results also show that incoming tourism has stimulated short-term and long-term economic growth in Nepal. In addition, the analysis point out a long-term one-way Granger causality from tourism to economic growth. It is recommended that policies that fascinate more international visitors should be promoted.
\end{abstract}

Keywords: Tourism; Economic growth; Financial Development; ARDL model

\section{INTRODUCTION}

Tourism is one of the productive activities aimed at producing goods and services. It provides goods and services to visitors, usually to foreigners and also provides income and jobs to local residents (Ohlan, 2017). Tourism has become fourth largest export industry of the world after food, fuel and chemicals. In particular, tourism accounts for $6 \%$ of the total exports of goods and services in the world, representing 30\% of international trade in services in 2015 (Goffi, Cucculelli, \& Masiero, 2018). In addition, over the same period $9.8 \%$ of global gross domestic product (GDP) accounted for the tourism sector. The inbound tourism impact on the national economy is fetching progressively important due to the tourist market growing size (Habibi, Rahmati, \& Karimi, 2018).The economic growth hypothesis (TLGH) in this circumstance recommends that the international tour expansion activity has led to economic growth. TLGH derives directly from the well-known export-oriented growth hypothesis (ELGH), which suggests that economic growth can be facilitated not only by expanding human resources and technology in the economy, but also by increasing foreign exchange earnings (Rivera, 2017). Through this travel business, businesses and people directly or indirectly associated receive income from the tourism industry. In addition, tourism as an economic activity has various direct, indirect and induced effects on the economy. It in the long run enlarged created jobs, 
foreign exchange earnings and increased revenue (Perles-Ribes, Ramón-Rodríguez, Rubia, \& MorenoIzquierdo, 2017).

The resulting flow of income circulates in the economy, encouraging other economic activities to occur, triggering multiple rounds of income. It also stimulates income and employment in other economic sectors (Puri, Akhil, Gaurav, Kush, \& Kumar, 2017). Tourism has numerous social, economic, environmental and cultural impacts on tourist destinations, and its impact can be negative and positive (Anton kakis et al., 2016). Some studies have attempted to measure the economic impact of tourism and to summarize its importance for the economy. Today, the importance of tourism in the economic development of many countries is well documented (Sun, 2016). On the other hand, Nepal lacks literature on the economic impact of tourism. The main purpose of this paper is to study the influence of tourism on economic growth in Nepal. The study is trying to determine the relationship between economic growth, tourism and financial development. The remainder part of the study is organized as the section II discuss the importance of tourism in Nepal, literature review is discussed in section III, the methodology of analysis and the empirical results are discussed in section IV and V in this paper.

\section{Importance of Tourism in Nepal}

The ability of the tourism sector to stimulate economic growth and employment at a faster rate than other economic sectors has prompted the Nepalese government to reform its tourism visa policy, develop infrastructure and rationalize luxury tax rates into best international practices. In addition, Govt. of Nepal recently developed the National Tourism Policy to promote the country as a honeymoon paradise (Khanal, 2017). In addition, the new Nepalese government has made tourism a key sector to achieve the overall goal of rapid economic growth. At present, the significance of tourism in the Nepalese economy is comparatively low. For instance, in 2016 only $6.7 \%$ of GDP was from this sector (Arai \& Goto, 2017). This means that Nepal's tourism industry has great untapped potential. In fact, the United Nations World Tourism Organization (2017) pointed out that Nepal is the strongest growth in international visitors' arrivals over the past decade. Given these reservations, it is important to understand whether the new government's efforts to turn Nepal into a tourist paradise will stimulate economic growth in the country.

Therefore, the main purpose of this study is to study whether and how Nepal's economic growth responds to the development of inbound tourism. Our motivation for choosing Nepal as an empirical attempt is that the country is one of the fastest growing Asian economies (Dhakal, 2017), which means its tourism industry is expected to grow faster in the next few years. Another notable feature of Nepal is its double-digit growth in international tourism revenue, with a compound annual growth rate of 11.23\% from 2006 to 2016 (Paudyal \& Prasad, 2017). Nepal is enthusiastic to encourage tourism globally, and it offers enormous natural and cultural advantages for those looking for vibrant destinations. It is clear that exploring the links between tourism and economic growth in Nepal enables policy makers to develop effective tourism policies.

\section{Literature Review}

To the best of our knowledge, different authors have compiled comprehensive survey of literature for the TLGH (Getz \& Page, 2016) and (Tugcu, 2014). To avoid repetition, different strands 
of the literature on tourism-growth nexus are provided here. First, on the dynamics of tourism and economic growth nexus different authors have found the support for the legitimacy of the tourismled growth hypothesis see (Ohlan, 2017) and (Shahzad, Shahbaz, Ferrer, \& Kumar, 2017). However, others maintained its contrast like economic growth promotes tourism, and not vice-versa (Marques, Fuinhas, \& Marques, 2017) and (Sokhanvar, 2018). This strand of literature holds the existence of the growth-led tourism hypothesis. Whilst, there are additionally a few studies (Jalil, Mahmood, \& Idrees, 2013) and (Atan \& Arslanturk, 2017), which propose either a feedback type link between tourism and growth. In regard to the influence of the size of a country on the link between tourism and growth empirically observed that only small countries were highly specialized in tourism (Aratuo \& Etienne, 2018). On the other hand, (Sokhanvar, Çiftçioğlu, \& Javid, 2018) conclude that country size does not influence the link between tourism and economic growth. On the issue of the effect of the level of economic development of a country on the dynamics of tourism and growth that tourism does not boost growth in developing countries (Venghaus \& Hake, 2018) and (Venghaus \& Hake, 2018), while the link between tourism and economic growth occurs in more developed countries see (Barrett, Barnett, \& Seth, 2010).

Some select studies investigating the relationship between tourism and financial development are briefly reviewed below. (May, 1991) estimated the impact of financial crisis of 2007 on tourism in Asia using autoregressive distributed lag model. It was found that the financial crisis had a negative impact on both inbound and outbound tourism in Asia. (Kumar, 2014) investigated whether money supply cycles in Canada, United Kingdom, and United States affected tourism demand cycles for Aruba and Barbados applying unit root, cointegration and causality testing . They found that money supply cycles could impact the cyclical movements of tourism demand and that the impacts were asymmetric, depending on the stage of development of the cycles. The author (Li, Jin, \& Shi, 2018) investigated the casual relationship between tourism, financial development, energy consumptions and carbon emissions in Turkey and four European Union countries, France, Spain, Italy and Greece, over the period 1995-2010. They found the existence of a feedback type causal relationship between the tourist arrivals and financial development. (Rakotondramaro \& Andriamasy, 2016) used a micro-ethnographic approach to analyze the role of informal microfinance institutions in development-led tourism entrepreneurship in Cameroon. They found that collective action in informal microfinance institutions enabled entrepreneurial members to create small tourism firms.

The empirical literature concerning applicability of TLGH in Nepal is scant to the extent that the findings of earlier studies are contradictory in nature which required more evidence. For instance, (Rieder, 2016) examined the cointegration between numbers of international tourist arrivals and economic growth over the period 1995 to 2015 using autoregressive distributed lag (ARDL) model. It was concluded that there is no long-run relationship between international tourist arrivals and economic growth, thus TLGH is not valid for Nepal. On the contrary, (Coles, Dinan, \& Warren, 2016) related international tourist arrivals with energy consumption and economic growth nexus for Nepal covering the period from 2000 to 2014 . Their results showed a feedback type relationship between international tourist arrivals and economic growth in Nepal. (Li et al., 2018) applying VECM (Johansen)-Granger's causality test on annual data on GDP, international tourism receipts and exchange rate and concluded that tourism promoted Nepal's long-run economic growth. The study 
of (Croes, Ridderstaat, \& van Niekerk, 2018) in sharp disagreement, using annual data on tourism expenditure, GDP and real effective exchange rate and failed to find the long-run causal link between tourism and economic growth in Nepal. Additionally various studies used different methodologies to perform different studies such as (Mohsin, Zhou, Iqbal, \& Shah, 2018), (Mohsin, Rasheed, \& Saidur, 2018) and (Ikram, Mahmoudi, Shah, \& Mohsin, 2019).

However, the extant empirical literature has limitations that the study aims to address. For instance, we observed that none of the above mentioned studies provided the estimates of the magnitude of the impact of tourism on Nepal's economic growth both in the short-run and long-run. In other words, the empirical literature on confirmation of TLGH looked generally at the presence of cointegration relationship and causality nexus while ignoring the economic growth elasticity with respect to tourism which is vital for policy discussion. In context of international literature as well, regarding the methodological structure used to examine the relationship between tourism and economic growth, the majority of the empirical studies relied upon (Parlett, Fletcher, \& Cooper, 1995). The majority of studies confirming validity of TLGH is confined to small economies. In addition, very little attention is paid to innovative accounting and variance decomposition analyses. Apart from these, there are very few studies considering the possible effect of structural breaks in investigation of the stationarity of the tourism series. In sum, the empirical literature on TLGH is less rigorous. Hence, it is clear that the validation of the applicability of TLGH in Nepal requires exact empirical estimation of the direct influence of inbound tourism on economic growth. The present study fills these important gaps in the literature by assessing the less explored link between tourism and economic growth in Nepal applying advance econometric techniques.

\section{Data and Methodology \\ Data Description}

The data used in the study is annual data for the period 2008-2016, including an endogenous GDP per capita and two exogenous variables financial development and per capita international tourism income. In this study the selected variables are based on the new theory of economic growth, which discusses that export expansion can encourage economic growth because it endorses specialization by increasing competition and increasing factor productivity, and creating positive externalities by promoting the dissemination of professional information and capabilities (Tugcu, 2014). The analysis of the inclusion of financial development in the tourism-led growth hypothesis is indeed one of the unique characteristics of the study, and in the case of Nepal, the missing variable bias is reduced because it is a theoretically and empirically recognized source of comparison advantage (Di Liberto, 2013).

\section{The Model Selection}

This study use the financial development as an additional variable in tourism and economic growth function for Nepal in order to avoid the problem of omitted-variable bias (Cárdenas-García, Sánchez-Rivero, \& Pulido-Fernández, 2015). The general functional form of the model for estimating the impact of tourism on economic growth is shown below in equation (1).

$$
\mathrm{GDP}_{\mathrm{t}}=\mathrm{f}\left(\mathrm{TER}_{\mathrm{t}} \times \mathrm{FDE}_{\mathrm{t}}\right)
$$


According to the existing literature, all data series have been converted to the natural logarithm (In) form, so the estimated coefficients represent elasticity and are valid. The log linear model can now be rendered as follows in equation (2).

$$
\operatorname{lnGDP} P_{t}=\operatorname{lnTER} R_{t}+\operatorname{lnFDE} E_{t}+\mu_{t}
$$

Where GDP indicates the GDP per capita, TER represents the international tourism earnings per capita, $\mathrm{t}$ is the time period, FDE denotes the financial development and $\mu=$ error term

\section{Cointegration Analysis}

The cointegration relationship amongst economic growth and tourism is examined by applying the joint cointegration test see (Bayer \& Hanck, 2013). This test provides uniform and reliable cointegration results by integrating the findings of four cointegration approaches, (Engle \& Granger, 1987), (Banerjee, Dolado, \& Mestre, 1998), (Johansen, 1995) and (Peter Boswijk, 1994) which are expressed by EG, JOH, BO and BDM respectively (Ohlan, 2017). This formula is presented as follows in equation (3):

$$
\mathrm{EG}=\mathrm{JOH}=\mathrm{BO}=\mathrm{BDM}=-2[\ln (P E G)+\ln (P J O H)+\ln (P B O)+\ln (P B D M)
$$

Where PEG, $\mathrm{PJOH}, \mathrm{PBO}$ and $\mathrm{PBDM}$ represent the probability values of $\mathrm{EG}, \mathrm{JOH}, \mathrm{BO}$ and $\mathrm{BDM}$ tests respectively. To conclude whether long-run association is present or not among the series, the Fisher statistic is applied.

In addition, the results of this test were confirmed by applying an autoregressive distributed lag (ARDL) model. Compare other cointegration methods, such as the two-step method proposed by (Johansen, 1995) and (Engle \& Granger, 1987). The ARDL cointegration model has certain econometric advantages. For example, the model does not need to have a single integral I (1). Estimates of long-term and short-term relationships can be obtained simultaneously. However, the limitation of the ARDL model is that if the series is a second order or I (2) integration, it cannot give any empirical estimates. From Eq. (2) the empirical version of the ARDL model determines the economic growth of Nepal. The relationship amongst tourism and financial development can be expressed as an equation. (4):

$$
\begin{gathered}
\Delta \ln G D P_{\mathrm{t}}=\beta_{0}+\sum_{\mathrm{i}=1}^{m} b_{\mathrm{i}} \Delta \ln G D P_{\mathrm{t}-\mathrm{i}}+\sum_{\mathrm{i}=0}^{\mathrm{n}} c_{\mathrm{i}} \Delta \ln T E R_{\mathrm{t}-\mathrm{i}}+\sum_{\mathrm{i}=0}^{0} d_{\mathrm{i}} \Delta \ln T E R_{\mathrm{t}-\mathrm{i}}+\phi_{1} \Delta \ln G D P_{\mathrm{t}-\mathrm{i}}+ \\
\phi_{2} \Delta \ln T E R_{\mathrm{t}-\mathrm{i}}+\phi_{3} \Delta \ln F D E_{\mathrm{t}-\mathrm{i}}+\mathrm{U}_{\mathrm{t}}
\end{gathered}
$$

Where $\phi_{1}, \phi_{2}$ and $\phi_{3}$ denotes the long-run dynamic relationship, $\Delta$ indicates the first difference operator, $\beta_{0}$ represents the constant, t shows time, $b_{\mathrm{i}}, c_{\mathrm{i}}$ and $d_{\mathrm{i}}$, di are the coefficients of short-run dynamics and $U_{t}$ denotes the error term. This test is based on the joint significance of F-statistic and the $\chi 2$ statistic of the Wald test. When the GDP per capita (InGDP) used as a dependent variable and international tourism receipts per capita (InTER) and financial development (InFDE) were assumed as the explanatory variables. The null of no cointegration hypothesis is examined by testing the joint significance of the $F$ statistic of $\varphi 1, \varphi 2, \varphi 3$. If the series are cointegrated, an error correction mechanism (ECM) can be developed as Eq. (5), which shows the short-run influence of tourism and financial development on Nepal's economic growth.

$$
\Delta \operatorname{lnGDP} \mathrm{P}_{\mathrm{t}}=\gamma_{0}+\sum_{\mathrm{i}=1}^{m} c_{\mathrm{i}} \Delta \ln G D P_{\mathrm{t}-\mathrm{i}}+\sum_{\mathrm{i}=0}^{\mathrm{n}} d_{\mathrm{i}} \Delta \ln T E R_{\mathrm{t}-\mathrm{i}}+\sum_{\mathrm{i}=0}^{0} e_{\mathrm{i}} \Delta \ln T E R_{\mathrm{t}-\mathrm{i}}+\psi_{1} E c m_{\mathrm{t}-\mathrm{i}}+v_{\mathrm{t}}(5)
$$

Where Ecm represents the error term correction, and $\psi$ indicates the error term correction coefficient which shows the pace of adjustment of the variables to equilibrium in long-run every year. 
INTERNATIONAL JOURNAL OF ACADEMIC RESEARCH IN BUSINESS AND SOCIAL SCIENCES

Vol. 9, No. 3, March, 2019, E-ISSN: 222 2-6990 @ 2019 HRMARS

\section{Results and Discussion}

Primarily we have evaluates the series of integrating properties by applying Philip Perron (PP) and Augmented Dicky-Fuller (ADF) unit root tests in order to confirm that the variables are not I(2). Table 2 represents the results of PP and ADF tests and the results show that the tourism, financial development and economic growth index are non-stationary at this level. The results of international tourism receipts per capita (InTERt), financial development (InFEDt) and GDP per capita (InGDPt) series are integrated of order one: I(1).

This empirical study supports the growing recognition that most macroeconomic series are I(1). The results of structural damage unit root test are shown in Table 3. These results confirm our earlier findings that despite the structural fractures, our variables are the first-order integration. Since the unit root test consistently indicates that all sequences have a single integral, the Bayer and Hanck (2013) tests are applicable to whether the study variables are cointegrated. Table 4 gives the results of the Bayer and Hanck (2013) cointegration tests. Table 4 clearly shows that the estimate of the Fisher statistic for the JOH-BDM-BO EG- test is larger than the table value of $5 \%$. Therefore, we reject the inefficiency of the co-integration hypothesis and conclude that tourism, financial development and economic growth are co-integrated. The results of the Bayer and Hank (2013) models further validate the application of the ARDL model based on the Schwarz Bayesian criterion (SBC).

Table 1 Results of ADF and PP unit root tests

\begin{tabular}{lccccc}
\hline Variable & \multicolumn{2}{c}{ ADF } & \multicolumn{2}{c}{ PP } & Implications \\
\cline { 2 - 5 } & Constant & $\begin{array}{c}\text { Constant and } \\
\text { trend }\end{array}$ & Constant & $\begin{array}{c}\text { Constant and } \\
\text { trend }\end{array}$ & \\
\hline InGDPt & $0.4463(0)$ & $-1.5885(0)$ & $0.4463(0)$ & $-1.7485(2)$ & Nonstationary \\
InTERt & $-0.7997(1)$ & $-2.0684(1)$ & $-0.5362(3)$ & $-1.8114(3)$ & Nonstationary \\
InFEDt & $0.6072(1)$ & $-2.4694(1)$ & $1.4035(1)$ & $-2.3436(1)$ & Nonstationary \\
$\Delta$ InGDPt & $-6.6532^{*}(0)$ & $-6.6581^{*}(0)$ & $-6.6532^{*}(0)$ & $-6.6580^{*}(1)$ & Stationary \\
$\Delta$ InTERt & $4.7493^{*}(0)$ & $-4.7049^{*}(0)$ & $-4.7738^{*}(1)$ & $-4.7286^{*}(1)$ & Stationary \\
$\Delta$ InFEDt & $-4.4457^{*}(0)$ & $-4.6251^{*}(0)$ & $-4.3912^{*}(3)$ & $-4.4223^{*}(4)$ & Stationary \\
\hline
\end{tabular}

Note: for ADF and PP tests () shows lags and bandwidths respectively and also * designates the rejection of the null of non-stationarity hypothesis at 1 per cent level of significance

Table $2 \mathrm{t}$ results of unit root test

\begin{tabular}{lccl}
\hline Variables & Constant & Constant and trend & Implications \\
\hline LnGDPt & $-1.6281(0)$ & $-2.8498(0)$ & Nonstationary \\
LnTERt & $-2.2346(1)$ & $-4.1916(1)$ & Nonstationary \\
LnFEDt & $-1.6728(1)$ & $-4.5213(1)$ & Nonstationary \\
$\Delta$ InGDPt & $-7.1615^{*}(0)$ & $-7.0604^{*}(0)$ & Stationary \\
$\Delta$ InTERt & $5.3385^{*}(0)$ & $-5.8667^{*}(0)$ & Stationary \\
$\Delta$ InFEDt & $4.9534^{*}(1)$ & $-5.5390^{*}(0)$ & Stationary \\
\hline
\end{tabular}


Table 5 shows that when InGDPt is used as the dependent variable, the estimate of the $F$ statistic is above the upper limit of the limit. Therefore, we reject the equation 4 for the null hypothesis H0: $\phi 1=\phi 2=\phi 3=0$. (4). As a result, we can conclude that InGDPt, InTERt and InFEDt are significantly cointegrated during the study period. After determining the cointegration relationship amongst variables, we studied the long-term and short-term effects of these variables on economic growth. According to Eq. (4) The principle of the minimum SBC value, we choose the ARDL $(1,0,1)$ model, and the long-term impact estimation is shown in Table 6. Obviously, our model fits very well with the statistically significant independent arguments of the data.

Table 3 Cointegration test results of Bayer and Hanck

\begin{tabular}{lccc}
\hline Variables & EG-JOH-BOBDM & $\begin{array}{c}\text { Critical value at 5 per } \\
\text { cent level }\end{array}$ & Implications \\
\hline $\begin{array}{l}\text { F(InGDPt, InTERt, } \\
\text { InFEDt) }\end{array}$ & $25.380^{*}$ & 21.106 & Cointegration \\
\hline
\end{tabular}

Note: At 5 per cent level of significance * shows rejection of the null hypothesis

Table 6 lists some comments. In short, tourism and financial development are positively correlated with economic growth and are statistically significant. In other words, in the long run, the increase in tourism and financial development will lead to economic growth. Details as follow. First, the growth in international tourism revenue has had a long-term and significant impact on Nepal's economic growth. Specifically, a $10 \%$ increase in per capita tourism income led to a $1.9 \%$ increase in per capita GDP. In terms of policy, our research shows that tourism will become an important catalyst for Nepal's economic growth. This is an important fact because the tourism industry in Nepal has never appeared.

Table 4 The Results of ARDL cointegration analysis

\begin{tabular}{lccccc}
\hline ARDL model & $\begin{array}{c}\text { Optimal lag } \\
\text { length }\end{array}$ & F-statistics & $\begin{array}{c}\text { Lower Bound } \\
\text { critical value } \\
\text { at } 5 \text { per cent } \\
\text { level }\end{array}$ & $\begin{array}{c}\text { Upper Bound } \\
\text { critical value } \\
\text { at } 5 \text { per cent } \\
\text { level }\end{array}$ & \\
\hline $\begin{array}{l}\text { F(InGDPt, } \\
\text { InTERt, InFEDt) }\end{array}$ & $(1,0,1)$ & $5.6570^{*}$ & 4.0461 & 5.1315 & Cointegration \\
* shows rejection of the null of no cointegration hypothesis at 5 per cent level of significance.
\end{tabular}

Table 5 Long Run Estimates from ARDL Model

\begin{tabular}{lccc}
\hline Variable & Coefficient & Standard Error & T-Ratio \\
\hline LnTERt & $0.1986^{*}$ & 0.0418 & $4.7455[0.000]$ \\
LnFEDt & $0.2700^{*}$ & 0.0378 & $7.1382[0.000]$ \\
Constant & $3.7977^{*}$ & 0.0838 & $45.3337[0.000]$ \\
\hline
\end{tabular}

Note. ${ }^{*}$ indicates significant at the 1 per cent level

Second, it was found that the expected financial development was positively correlated with economic growth. Rather, a $10 \%$ increase in financial development may be linked to a $2.7 \%$ increase in long-term economic growth, with all other factors remaining unchanged. This empirical 
evidence is consistent with the findings of Hassan et al. (2011) is a group of South Asian countries. Next, in order to obtain an estimate of the short-term impact of tourism on Nepal's economic growth, an error correction method was adopted. The results of the short-term analysis are given in Table 7. The estimated ECMt- 1 was found to be statistically significant at the $1 \%$ level and had a negative sign. This finding confirms the early cointegration between tourism and economic growth and shows the pace of adjustment from a short- to long-term equilibrium path. The error correction factor indicates that the short-term difference in long-term equilibrium economic growth is adjusted by $35 \%$ annually. The results show that tourism has a statistically significant positive impact on economic growth. It can be seen that tourism is also the engine of economic growth in the short term. Per capita international tourism income has increased by $5 \%$, per capita GDP has increased by $0.35 \%$, and other conditions have remained unchanged. In the short run, the financial development coefficient can be ignored.

\begin{tabular}{lccc}
\hline Variable & Coefficient & Standard Error & T-Ratio \\
\hline LnTERt & $0.0707^{*}$ & 0.0212 & $3.3382[0.002]$ \\
LnFEDt & 0.0973 & 0.0666 & $-1.4606[0.150]$ \\
ECMt-1 & $0.3559^{*}$ & 0.0767 & $-4.6396[0.000]$ \\
Diagnostic tests & R2 $=0.3434 ;$ F-Stat. F $(3,50)$ 1/4 $8.5438^{*}[0.000] ;$ DW-statistic $=1.6703$ \\
\hline
\end{tabular}

Shows significance at 1 per cent level

In the following, an assessment of long-term and short-term elasticity coefficients shows that economic growth has a long term rejoinder to tourism rather than short-term. This shows that as time goes by, the growth of Nepal's international tourism revenue will make economic growth more active. The calculated values of the $\mathrm{F}$ statistic given in the last row of Table 7 were statistically significant at the $1 \%$ significance level. This means that the overall adaptability of the model used is good. For our model, Durbin-Watson's statistic is less than 2, which means there is no autocorrelation problem. In addition, the R2 value is 0.34 , which indicates that these independent individuals can explain $34 \%$ of economic growth change information in a short period of time, and other factors can be interpreted as $66 \%$. In addition, due to structural changes in the country, Nepal's macroeconomic series may have witnessed structural breakthroughs. This result corroborates the similar finding of (Ohlan, 2017) in the case of India.

\section{Conclusion and Policy Recommendations}

This research empirically investigates the long-term and short-term effects of incoming tourism on economic growth of Nepal. To achieve this, the smoothness of the variables was tested by applying a breakpoint unit root test (Vogelsang \& Perron, 1998). Therefore all variables used in the study are I(1) according to our findings. Evidence of a tourism-led growth hypothesis has been established for Nepal. To cointegration the study used the ARDL modeling approach (Katircioglu, 2009).

The ARDL cointegration method empirical results constantly show that tourism, economic growth and financial development of Nepal are co-integration. This approach can achieve the economic growth elasticity of tourism in the long-term and short-term. It is worth noting that we have found that the benefits of international tourism have had a positive impact on Nepal's economic growth in the long run and in the short run. As international tourism revenues increase by $1 \%$, Nepal's 
GDP grew by an average of $0.2 \%$ in the long run. The parameter estimates were found to be stable during the sample period. It is worth noting that we found a one-way long-term causal relationship between tourism and tourism in Nepal. This means that inbound tourism revenues are ahead of GDP growth. These empirical findings further support the broad applicability of the tourism-led growth hypothesis.

On the policy front, our findings provide a justification for the Nepalese government's goal of financing in tourism as a means of long-term economic growth. Tourism can rely on stimulating Nepal's economic prosperity, so policy makers should seriously consider encouraging inbound tourism.

\section{References}

Antonakakis, N., Dragouni, M., Eeckels, B., \& Filis, G. (2016). Tourism and economic growth: Does democracy matter? Annals of Tourism Research, 61, 258-264. https://doi.org/10.1016/J.ANNALS.2016.09.018

Arai, T., \& Goto, M. (2017). A Survey on Present Tourism in Nepal and Its Ripple Effects on Other Industries. Environment and Ecology Research, 5(7), 467-475. https://doi.org/10.13189/eer.2017.050701

Aratuo, D. N., \& Etienne, X. L. (2018). Industry level analysis of tourism-economic growth in the United States. Tourism Management, 70, 333-340. https://doi.org/10.1016/J.TOURMAN.2018.09.004

Atan, S., \& Arslanturk, Y. (2017). Tourism and Economic Growth Nexus: An Input Output Analysis in Turkey. Procedia - Social and Behavioral Sciences, 62, 952-956. https://doi.org/10.1016/J.SBSPRO.2012.09.162

Banerjee, A., Dolado, J., \& Mestre, R. (1998). Error-correction Mechanism Tests for Cointegration in a Single-equation Framework. Journal of Time Series Analysis, 19(3), 267-283. https://doi.org/10.1111/1467-9892.00091

Barrett, A. B., Barnett, L., \& Seth, A. K. (2010). Multivariate Granger causality and generalized variance. Physical Review E - Statistical, Nonlinear, and Soft Matter Physics, 81(4). https://doi.org/10.1103/PhysRevE.81.041907

Bayer, C., \& Hanck, C. (2013). Combining non-cointegration tests. Journal of Time Series Analysis, 34(1), 83-95. https://doi.org/10.1111/j.1467-9892.2012.00814.x

Cárdenas-García, P. J., Sánchez-Rivero, M., \& Pulido-Fernández, J. I. (2015). Does Tourism Growth Influence Economic Development? Journal of Travel Research, 54(2), 206-221. https://doi.org/10.1177/0047287513514297

Coles, T., Dinan, C., \& Warren, N. (2016). Energy practices among small- and medium-sized tourism enterprises: a case of misdirected effort? Journal of Cleaner Production, 111, 399-408. https://doi.org/10.1016/J.JCLEPRO.2014.09.028

Croes, R., Ridderstaat, J., \& van Niekerk, M. (2018). Connecting quality of life, tourism specialization, and economic growth in small island destinations: The case of Malta. Tourism Management, 65, 212-223. https://doi.org/10.1016/J.TOURMAN.2017.10.010

Dhakal, B. (2017). Using Factor Analysis for Residents ' Attitudes towards Economic Impact of Tourism in Nepal, 7(5), 250-257. https://doi.org/10.5923/j.statistics.20170705.02 
INTERNATIONAL JOURNAL OF ACADEMIC RESEARCH IN BUSINESS AND SOCIAL SCIENCES

Vol. 9, No. 3, March, 2019, E-ISSN: 222 2-6990 @ 2019 HRMARS

Di Liberto, A. (2013). High skills, high growth: Is tourism an exception? The Journal of International Trade \& Economic Development, 22(5), 749-785. https://doi.org/10.1080/09638199.2011.603054

Engle, R. F., \& Granger, C. W. J. (1987). Co-Integration and Error Correction: Representation, Estimation, and Testing. Econometrica, 55(2), 251. https://doi.org/10.2307/1913236

Getz, D., \& Page, S. J. (2016). Progress and prospects for event tourism research. Tourism Management, 52, 593-631. https://doi.org/10.1016/J.TOURMAN.2015.03.007

Goffi, G., Cucculelli, M., \& Masiero, L. (2018). Fostering tourism destination competitiveness in developing countries: The role of sustainability. Journal of Cleaner Production, 209, 101-115. https://doi.org/10.1016/J.JCLEPRO.2018.10.208

Habibi, F., Rahmati, M., \& Karimi, A. (2018). Contribution of tourism to economic growth in Iran's Provinces: GDM approach. Future Business Journal, 4(2), 261-271. https://doi.org/10.1016/J.FBJ.2018.09.001

Ikram, M., Mahmoudi, A., Shah, S. Z. A., \& Mohsin, M. (2019). Forecasting number of ISO 14001 certifications of selected countries: application of even GM (1,1), DGM, and NDGM models. Environmental Science and Pollution Research. https://doi.org/10.1007/s11356-019-04534-2

Jalil, A., Mahmood, T., \& Idrees, M. (2013). Tourism-growth nexus in Pakistan: Evidence from ARDL bounds tests. Economic Modelling, 35, 185-191. https://doi.org/10.1016/J.ECONMOD.2013.06.034

Johansen, S. (1995). Identifying restrictions of linear equations with applications to simultaneous equations and cointegration. Journal of Econometrics, 69(1), 111-132. https://doi.org/10.1016/0304-4076(94)01664-L

Katircioglu, S. T. (2009). Revisiting the tourism-led-growth hypothesis for Turkey using the bounds test and Johansen approach for cointegration. Tourism Management, 30(1), 17-20. https://doi.org/10.1016/J.TOURMAN.2008.04.004

Khanal, B. (2017). Issues and Challenges of Integrative Medical System to the Growth of Health Tourism Industry in Nepal. Travel and Tourism Research Association: Advancing Tourism Research Globally.

Kumar, R. R. (2014). Exploring the role of technology, tourism and financial development: an empirical study of Vietnam. Quality \& Quantity, 48(5), 2881-2898. https://doi.org/10.1007/s11135-013-9930-5

Li, K. X., Jin, M., \& Shi, W. (2018). Tourism as an important impetus to promoting economic growth: A critical review. Tourism Management Perspectives, 26, 135-142. https://doi.org/10.1016/J.TMP.2017.10.002

Marques, L. M., Fuinhas, J. A., \& Marques, A. C. (2017). Augmented energy-growth nexus: economic, political and social globalization impacts. Energy Procedia, 136, 97-101. https://doi.org/10.1016/J.EGYPRO.2017.10.293

May, V. (1991). Tourism, environment and development: Values, sustainability and stewardship. Tourism Management, 12(2), 112-118. https://doi.org/10.1016/0261-5177(91)90065-2

Mohsin, M., Rasheed, A. K., \& Saidur, R. (2018). Economic viability and production capacity of wind generated renewable hydrogen. International Journal of Hydrogen Energy, 43(5), 2621-2630. https://doi.org/10.1016/j.ijhydene.2017.12.113 
INTERNATIONAL JOURNAL OF ACADEMIC RESEARCH IN BUSINESS AND SOCIAL SCIENCES

Vol. 9, No. 3, March, 2019, E-ISSN: 222 2-6990 @ 2019 HRMARS

Mohsin, M., Zhou, P., Iqbal, N., \& Shah, S. A. A. (2018). Assessing oil supply security of South Asia. Energy, 155, 438-447. https://doi.org/10.1016/J.ENERGY.2018.04.116

Ohlan, R. (2017). The relationship between tourism, financial development and economic growth in India. Future Business Journal, 3(1), 9-22. https://doi.org/10.1016/J.FBJ.2017.01.003

Parlett, G., Fletcher, J., \& Cooper, C. (1995). The impact of tourism on the Old Town of Edinburgh. Tourism Management, 16(5), 355-360. https://doi.org/10.1016/0261-5177(95)00038-P

Paudyal, B. P., \& Prasad, B. (2017). Problem and Prospects of Tourism in Nepal.

Perles-Ribes, J. F., Ramón-Rodríguez, A. B., Rubia, A., \& Moreno-Izquierdo, L. (2017). Is the tourismled growth hypothesis valid after the global economic and financial crisis? The case of Spain 1957-2014. Tourism Management, 61, 96-109. https://doi.org/10.1016/J.TOURMAN.2017.01.003

Peter Boswijk, H. (1994). Testing for an unstable root in conditional and structural error correction models. Journal of Econometrics, 63(1), 37-60. https://doi.org/10.1016/0304-4076(93)01560-9

Puri, C., Akhil, Gaurav, Kush, \& Kumar, N. (2017). Opinion Ensembling for Improving Economic Growth through Tourism. Procedia Computer Science, 122, 237-244. https://doi.org/10.1016/J.PROCS.2017.11.366

Rakotondramaro, H., \& Andriamasy, L. (2016). Multivariate Granger Causality among tourism, poverty and growth in Madagascar. Tourism Management Perspectives, 20, 109-111. https://doi.org/10.1016/J.TMP.2016.08.005

Rieder, S. (2016). Interrogating the global health and development nexus: Critical viewpoints of neoliberalization and health in transnational spaces. World Development Perspectives, 2, 5561. https://doi.org/10.1016/J.WDP.2016.10.004

Rivera, M. A. (2017). The synergies between human development, economic growth, and tourism within a developing country: An empirical model for ecuador. Journal of Destination Marketing \& Management, 6(3), 221-232. https://doi.org/10.1016/J.JDMM.2016.04.002

Shahzad, S. J. H., Shahbaz, M., Ferrer, R., \& Kumar, R. R. (2017). Tourism-led growth hypothesis in the top ten tourist destinations: New evidence using the quantile-on-quantile approach. Tourism Management, 60, 223-232. https://doi.org/10.1016/J.TOURMAN.2016.12.006

Sokhanvar, A. (2018). Does foreign direct investment accelerate tourism and economic growth within Europe? Tourism Management Perspectives, 29, 86-96. https://doi.org/10.1016/j.tmp.2018.10.005

Sokhanvar, A., Çiftçioğlu, S., \& Javid, E. (2018). Another look at tourism- economic development nexus. Tourism Management Perspectives, 26, 97-106. https://doi.org/10.1016/J.TMP.2018.03.002

Sun, Y. Y. (2016). Decomposition of tourism greenhouse gas emissions: Revealing the dynamics between tourism economic growth, technological efficiency, and carbon emissions. Tourism Management, 55, 326-336. https://doi.org/10.1016/J.TOURMAN.2016.02.014

Tugcu, C. T. (2014). Tourism and economic growth nexus revisited: A panel causality analysis for the case of the Mediterranean Region. Tourism Management, 42, 207-212. https://doi.org/10.1016/J.TOURMAN.2013.12.007

Venghaus, S., \& Hake, J.-F. (2018). Nexus thinking in current EU policies - The interdependencies among food, energy and water resources. Environmental Science \& Policy, 90, 183-192. 
INTERNATIONAL JOURNAL OF ACADEMIC RESEARCH IN BUSINESS AND SOCIAL SCIENCES

Vol. 9, No. 3, March, 2019, E-ISSN: 222 2-6990 @ 2019 HRMARS

https://doi.org/10.1016/J.ENVSCI.2017.12.014

Vogelsang, T. J., \& Perron, P. (1998). Additional Tests for a Unit Root Allowing for a Break in the Trend Function at an Unknown Time. International Economic Review, 39(4), 1073.

https://doi.org/10.2307/2527353 